Dhaka Univ. J. Sci. 62(2): 127-132, 2014 (July)

\title{
Modeling and Simulation of a PV Module Based Power System Using MATLAB/Simulink
}

\author{
Protap Kumar Mahanta*, Khokan Debnath and Md.Habibur Rahman
}

Department of Applied Physics, Electronics and Communication Engineering, Dhaka University, Dhaka-1000, Bangladesh

(Received: 30 August 2013; Accepted: 5 March 2014)

\begin{abstract}
Due to the variation of solar irradiance, temperature and shading conditions, the power generated by a photovoltaic (PV) module and hence the power delivered to the load changes drastically, which imposes the need for analysis of a complete PV system to get the maximum power under these natural variable conditions. In this paper, a complete off-grid PV module based power generation system has been designed and simulated using MATLAB/Simulink and performance has been scrutinized using the value of standard solar irradiance about $1 \mathrm{KW} / \mathrm{m}^{-2}$ for Bangladesh. The simulation model includes solar PV module, the converter power stage with MPPT control and charge controlling functions and here performance of each block has been examined conspicuously. Eventually, it has been found that the model is quite competent to simulate both the I-V and P-V characteristics of a PV module and based on the result it has been predicted that the performance of several modules or even PV array connected in series and/or in parallel with the delivery of maximum power can be tested under different solar irradiance and temperature conditions.
\end{abstract}

Key Words: PV module, Maximum Power, Matlab/Simulink.

\section{Introduction}

The problem of energy quandary is becoming more and more exacerbating, resulting in increased exploitation and research for new power energy resources such as wind, water, geothermal and solar energy around the world in the 21 st century ${ }^{1,2}$. Solar energy is green energy, which is inexhaustible and environmentally friendly. Due to this natural vantage, photovoltaic solar energy has been immensely used to generate electric power from sunshine ${ }^{3-5}$. A PV solar device, cell, or module converts solar energy directly into electrical energy. Solar energy obtained from a solar PV cell is not constant all the time. The amount of extracted power from a PV system is a function of the PV module voltage and current set point ${ }^{6-10}$. Furthermore the power is affected by external conditions like solar irradiance and temperature. Under uniform solar irradiance level with no partial shading, the nonlinear current-voltage (I-V) characteristics of a PV solar module will have one optimal operating point corresponding to a unique maximum power point (MPP) on its power-voltage $(\mathrm{P}-\mathrm{V})$ curve. In practice, since a solar module is composed of many solar cells which are connected with each other in series and/or in parallel, if some cells are on the temperature or irradiance variation the $\mathrm{P}-\mathrm{V}$ characteristics of solar modules becomes very complicated as multiple maximum power points exist on the $\mathrm{P}-\mathrm{V}$ characteristic curves ${ }^{11-14}$. Due to the complex behavior of a PV solar module under different illumination conditions, it is of need to build a simulation model to thoroughly investigate power, voltage and current relationship of a PV module under varying surrounding conditions.

There are works ${ }^{5-8}$ pertinent to modeling and simulation of PV module based power system under natural varying conditions, but there is hardly any work related to standard solar radiation of Bangladesh. This paper mainly focuses the performance of a PV system by Matlab/simulink model under the standard solar radiation variation of Bangladesh.

\section{Modeling of a PV Module Based Power System}

A PV cell is a simple PN junction ${ }^{8,10}$ which is fabricated in a layer of semiconductor material ${ }^{8}$. When it is illuminated by sunlight of photons with the energy equal or slightly greater than the band gap energy of semiconductor material, it is absorbed and the valence electrons are knocked out from the atoms in the material, and create electron-hole pairs ${ }^{9}$. These photo generated carries are swept apart by the internal electric fields of this cell and if the cell is connected by external circuit, they contribute to current.

\section{(a) Modeling of a Solar PV Cell and Module}

In order to create a more accurate model of a PV cell, series resistance, parallel resistance, and recombination must be counted in the circuit model which can be represented as in Fig.1

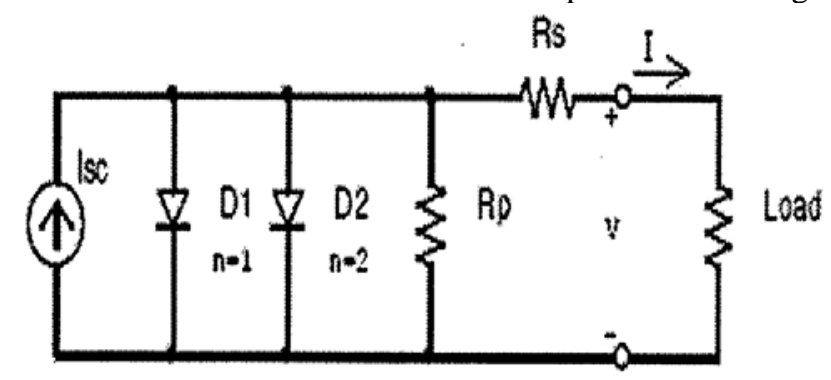

Fig.1. Equivalent circuit of a PV cell ${ }^{15}$.

From Fig.1, the output current of this cell can be expressed as follows:

$$
\mathrm{I}=\mathrm{I}_{\mathrm{sc}}-\mathrm{I}_{0} *\left(\mathrm{e}^{\mathrm{q}^{*}\left(\mathrm{~V}+\mathrm{I} * \mathrm{R}_{\mathrm{s}}\right) /(\mathrm{k} * \mathrm{~T})}-1\right)-\left(\mathrm{V}+\mathrm{I}^{*} \mathrm{R}_{\mathrm{s}}\right) / \mathrm{R}_{\mathrm{p}}
$$

Where $I_{s c}$ is the short-circuit current, $I_{0}$ is the reverse saturation current of the diode, $\mathrm{q}$ is the electron charge $\left(1.602 \times 10^{-23} \mathrm{C}\right), \mathrm{k}$ is the Boltzmann's constant $\left(1.381 \times 10^{-}\right.$ $\left.{ }^{23} \mathrm{~J} / \mathrm{K}\right)$, $\mathrm{T}$ is the junction temperature in Kelvin ${ }^{15}$.

The effect of the shunt resistance is minimal for a small number of modules. Therefore, we can assume $R_{p}=$ simplify the photon-generated current equation (1) into (2)

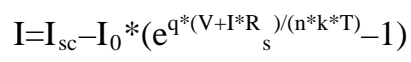

Equation (2) can be solved by using Newton's method, which can be described as

$$
X_{n+1}=x_{n}-f\left(X_{n}\right) / f^{\prime}\left(X_{n}\right)
$$


Where $f^{\prime}\left(X_{n}\right)$ is the derivative of the function $f(X), X_{n}$ is a present value, and $X_{n+1}$ is the next value. Now using equation (3), equation (2) can be written as

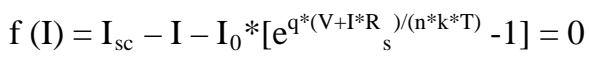

Then using Newton Raphson's equation for $\mathrm{n}^{\text {th }}$ iteration, we have

$$
\begin{aligned}
& I_{n+1}= I_{n}-\left(I_{s c}-I_{n}-I_{0} \times\left[e^{q \times \frac{V+I_{n} \times R_{s}}{n \times k \times T}}-1\right]\right) /\left(-1-I_{0} \times\right. \\
&\left.q \times R_{s} \times e^{q \times\left(V+I_{n} \times R_{s}\right) /(n \times k \times T) /(n \times k \times T)}\right)
\end{aligned}
$$

By coding this equation, a PV module block has been generated in Matlab/Simulink.

\section{(b) Modeling of a MPPT}

A MPPT strategy is to force the solar cells to operate in an optimal point, giving out maximum power according to the solar radiation condition at that time. The variation of $\mathrm{P}-\mathrm{V}$ characteristic according to solar radiation variation can be shown as ${ }^{16}$ follows

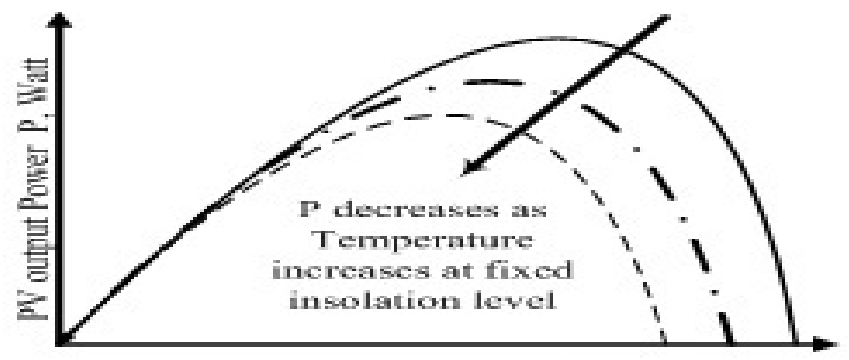

(a)

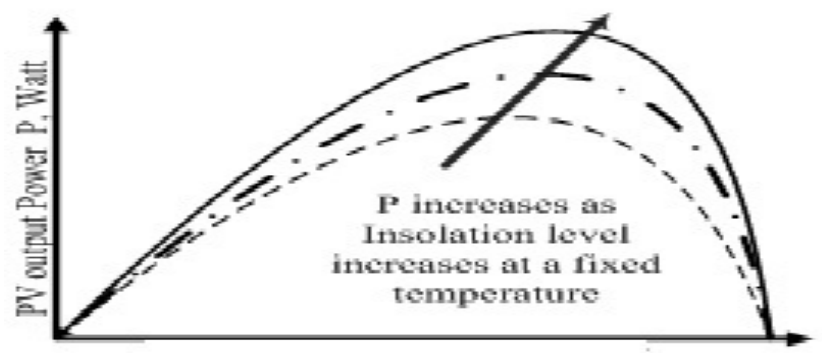

(b)

Fig. 2. P-V characteristic of a solar module at (a) different irradiation levels, (b) different temperatures.

Many MPPT techniques ${ }^{5-7}$ have been proposed, analyzed and implemented and among them Perturb and Observation (P\&O) method (Hill Climbing Method) is being used maximally because of its simplicity and ease of implementation. Basically, in this method the module voltage is perturbed by a small increment, and the resulting change in power is observed as in the algorithm ${ }^{16}$ of Fig.3

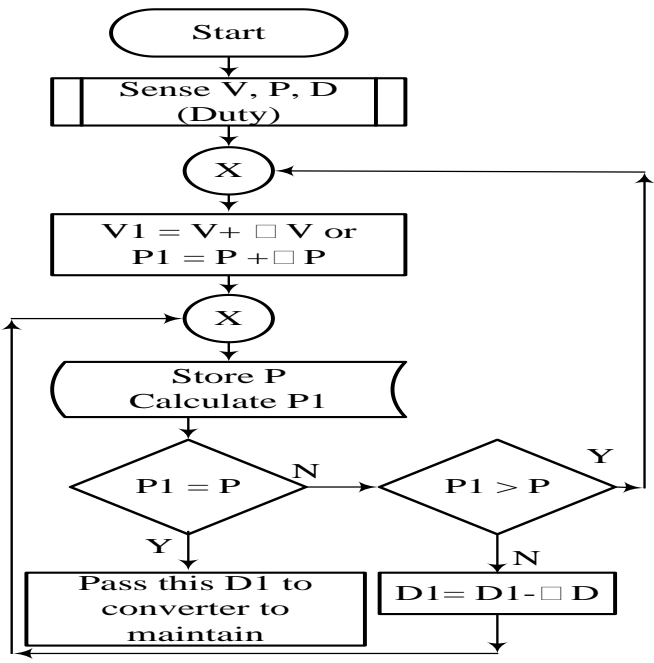

Fig. 3. Flowchart for Perturb and Observation method to track the $\mathrm{MPP}^{16}$.

\section{(c) Modeling of a Buck-Converter}

DC-DC converter is power electronics circuits that convert a dc voltage to a different dc voltage level. A DC-DC converter is used to increase the efficiency of the system by matching the voltage supplied to the voltage required by the load. A DC-DC converter can either be step-up (Boost), step-down (Buck), or both increase and decrease (BuckBoost) the voltage. The DC-DC converter used by this system is a Buck converter ${ }^{17}$ as in Fig.4

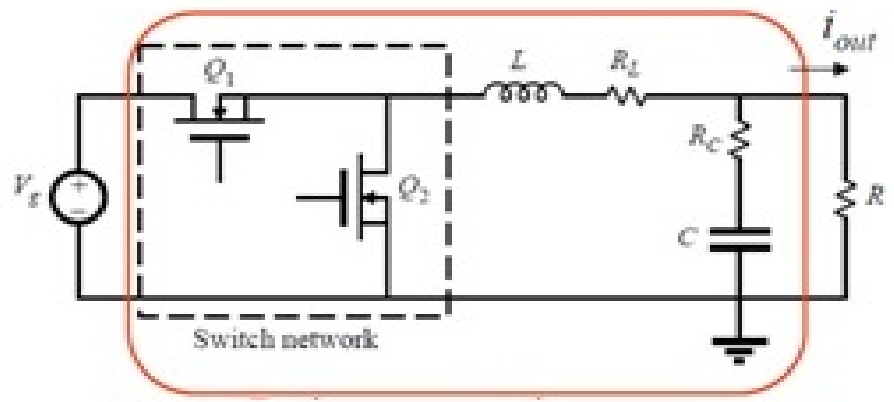

Fig. 4. Buck Converter.

Applying Kirchhoff's Voltage Law for Fig.4, we get,

$$
\frac{d i_{L}}{d t}=\frac{1}{L}\left(\mathrm{~V}_{\mathrm{g}} \mathrm{D}-i_{L} R_{L}-V_{0}\right)
$$

Current across the capacitor is, $\quad \frac{d V_{c}}{d t}=\frac{1}{C}\left(\mathrm{i}_{\mathrm{L}}-\mathrm{i}_{\text {out }}\right)$

And output voltage is,

$$
\mathrm{V}_{0}=\mathrm{V}_{\mathrm{c}}+\mathrm{R}_{\mathrm{C}}\left(\mathrm{i}_{\mathrm{L}}-\mathrm{i}_{\text {out }}\right)
$$

Here, $\mathrm{D}$ is the duty cycle of the buck-converter, $\mathrm{V}_{\mathrm{g}}$ is the Source voltage, $\mathrm{V}_{0}$ is voltage across the load, $\mathrm{i}_{\mathrm{L}}$ is Inductor current, $\mathrm{i}_{\text {out }}$ is load Current.

Based on equations (6), (7) and (8), the Simulink model of Buck converter has been designed as in the Fig.5. 


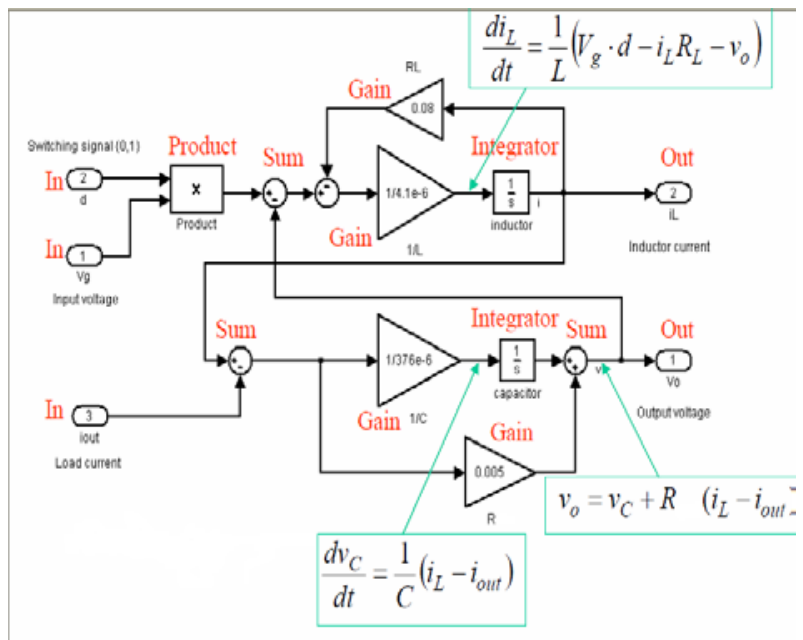

Fig. 5. Simulink Model of a Buck- Converter.

\section{(d) Modeling of PWM}

Traditionally the voltage mode was used in designing the feedback loop. The ramp signal is derived from the oscillator using a simple RC time constant network ${ }^{18}$. The saw tooth linearly varies with time and using the slope of the saw tooth waveform as shown in Fig.5, it can be easily deduced that

$$
\mathrm{d}(\mathrm{t})=\frac{V_{C}}{V_{M}}(\mathrm{t}) \text { for } 0 \leq \mathrm{V}_{\mathrm{C}}(\mathrm{t}) \leq \mathrm{V}_{\mathrm{M}}
$$

Small signal variation of the duty cycle with the control voltage is obtained by substituting Vc (t) by ac and dc quantities and taking the partial derivative of duty cycle with respect to control voltage.

$$
\frac{d^{\wedge}(t)}{V^{\wedge} C(t)}=\frac{1}{V_{M}}
$$

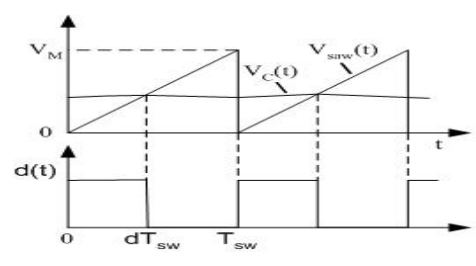

Fig. 6. PWM voltage mode control.

Using equations (9) and (10) the Simulink model has been designed as follows

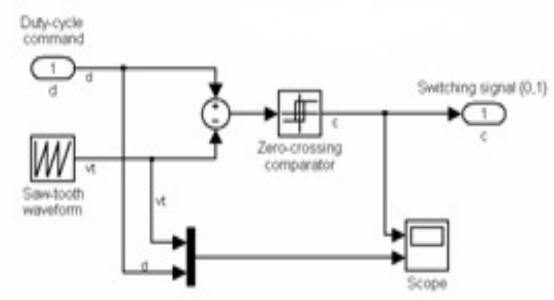

Fig. 7. Simulink model of PWM.

\section{(e) Charge Controller}

The charge controller consists of two switches, one on either side of battery's positive terminal. Switch A, on the PV module side, is opened if the battery voltage becomes 14.4 volt (approximately 100\% charged) and will remain open until the battery voltage has dropped to $13.4 \mathrm{~V}$. Switch B, on the load side, is opened if the battery voltage drops below $11.5 \mathrm{~V}$ (21\% charged) and will remain in that state until the voltage has rebounded to $12.5 \mathrm{~V}^{19,20}$.

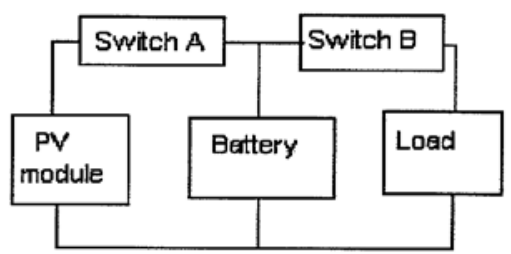

Fig. 8. Block diagram of series charge regulation.

To implement the controlling functions of Fig.8, the charge ontroller model has been designed as

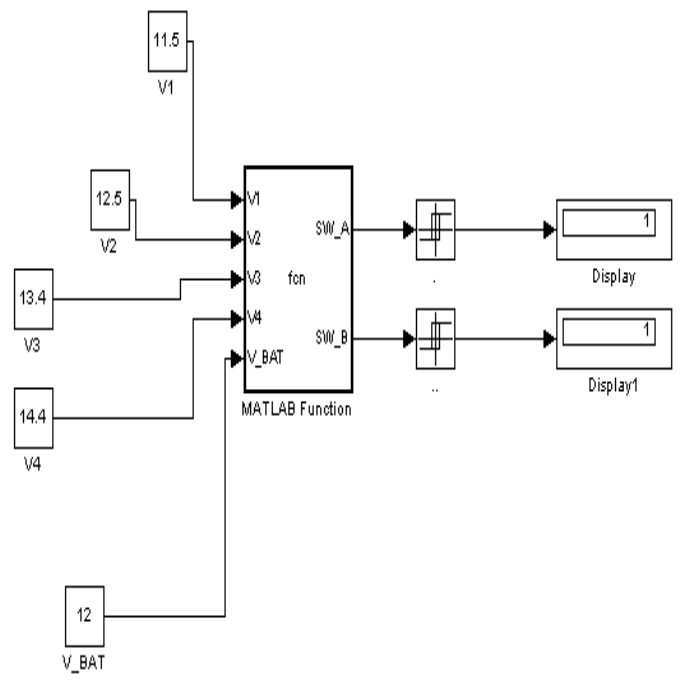

Fig. 9. Charge controller implemented by Simulink/ MATLAB function.

\section{(f) Modeling of a Battery}

The battery with its charge controlling function according to theory of ${ }^{19,20}$ has been modeled as in the Fig.10

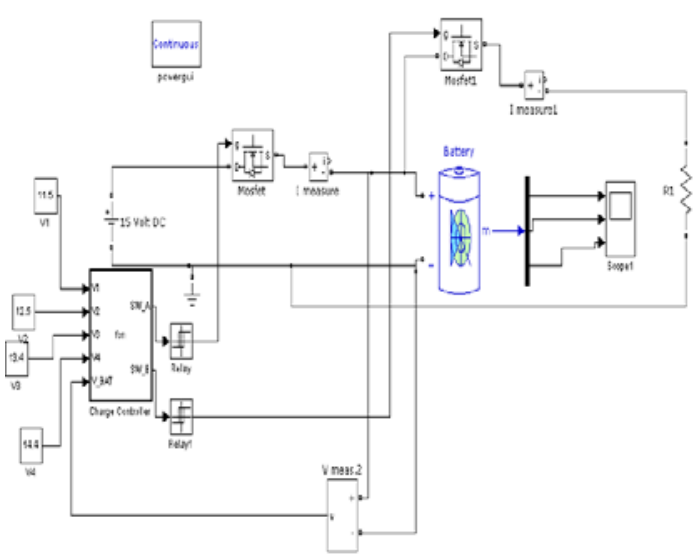

Fig. 10. Simulink model of Battery block coupled with Charge Controller and Load. 


\section{Results of Simulation}

Finally the PV module with its different components has been designed as follows

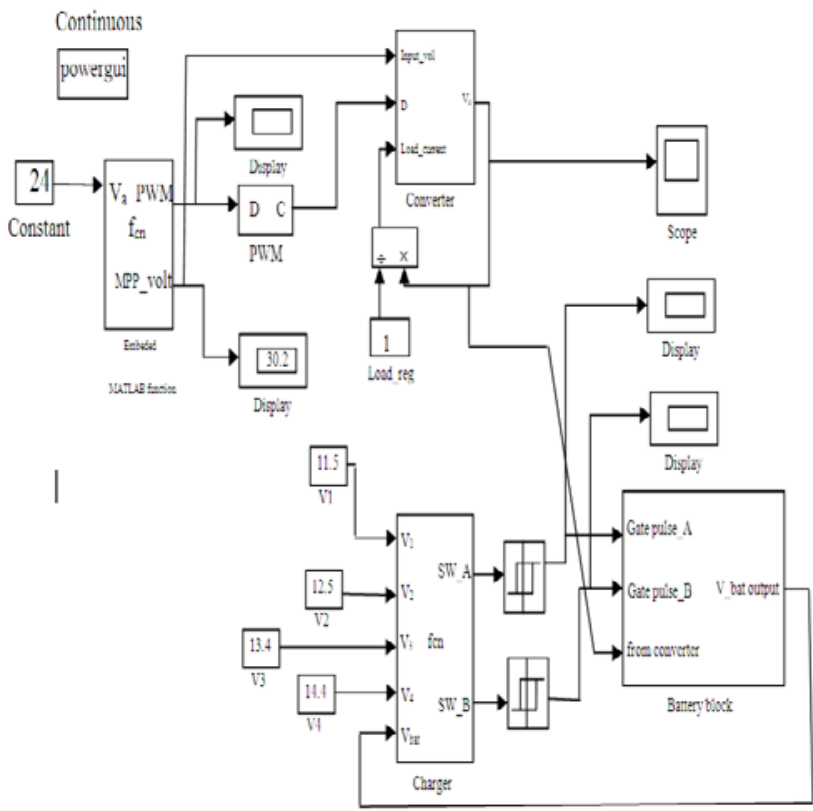

Fig. 11. A complete PV module based power generating system that integrated with its different components.

Here the BP SX 150PV module, which contains 72 cells, has been selected to ratify the system under irradiation and temperature variation. Data sheet for the BP SX 150 provides the information of the module ${ }^{21}$ as in Table.1.

Table 1. Data sheet for the BP SX 150

\begin{tabular}{|l|l|}
\hline Electrical Characteristics & BP SX 150S \\
\hline Maximum power (Pmax) & $150 \mathrm{~W}$ \\
\hline Voltage at Pmax (Vmp) & $34.5 \mathrm{~V}$ \\
\hline Current at Pmax (Imp) & $4.35 \mathrm{~A}$ \\
\hline Warranted minimum Pmax & $140 \mathrm{~W}$ \\
\hline Short-circuit current (Isc) & $4.75 \mathrm{~A}$ \\
\hline Open-circuit voltage (Voc) & $43.5 \mathrm{~V}$ \\
\hline Temperature coefficient of Isc & $(0.065 \pm 0.015)^{\circ} /{ }^{\circ} \mathrm{C}$ \\
\hline Temperature coefficient of Voc & $-(160 \pm 20) \mathrm{mV} /{ }^{\circ} \mathrm{C}$ \\
\hline Temperature coefficient of power & $-(0.5 \pm 0.05)^{\%} /{ }^{\circ} \mathrm{C}$ \\
\hline NOCT & $47 \pm 2^{\circ} \mathrm{C}$. \\
\hline Maximum system voltage & $600 \mathrm{~V}(\mathrm{U} . S$. NEC rating) \\
\hline
\end{tabular}

\section{(a) Output of PV Module}

For a sample Temperature $\mathrm{T}=62^{\circ} \mathrm{C}$, Irradiance, $\mathrm{G}=1 \mathrm{KW} / \mathrm{m}^{-2}$, Module voltage range from 0 to $39 \mathrm{~V}$, the simulated IV and PV curves are shown in the Fig.12 and Fig.13 respectively.

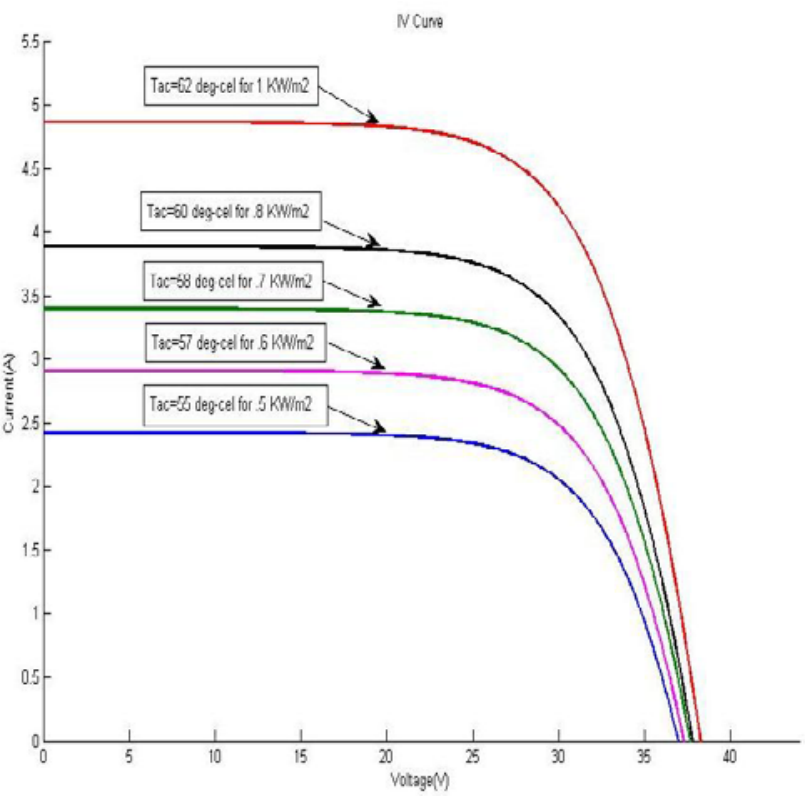

Fig. 12. I-V Curves after Simulation

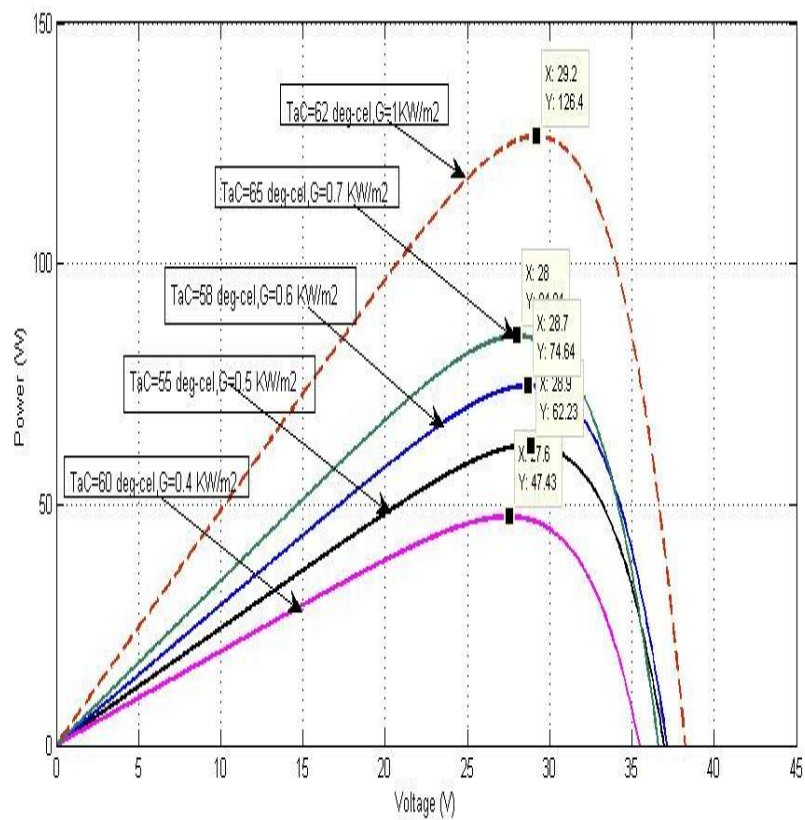

Fig. 13. PV Curves after Simulation

(b) Output of PWM

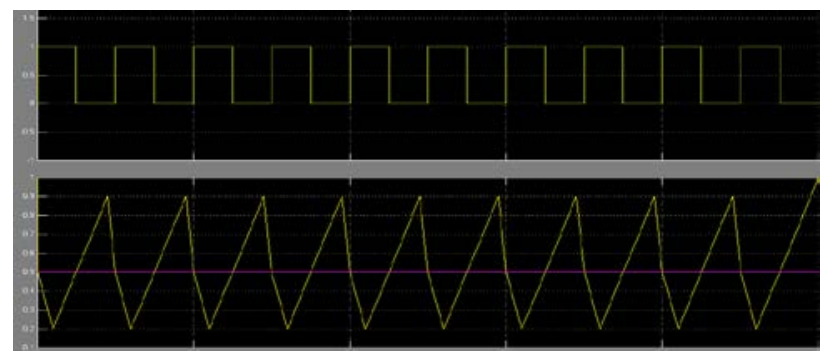

Fig. 14. PWM generation and output voltage waveform from Buck-converter 


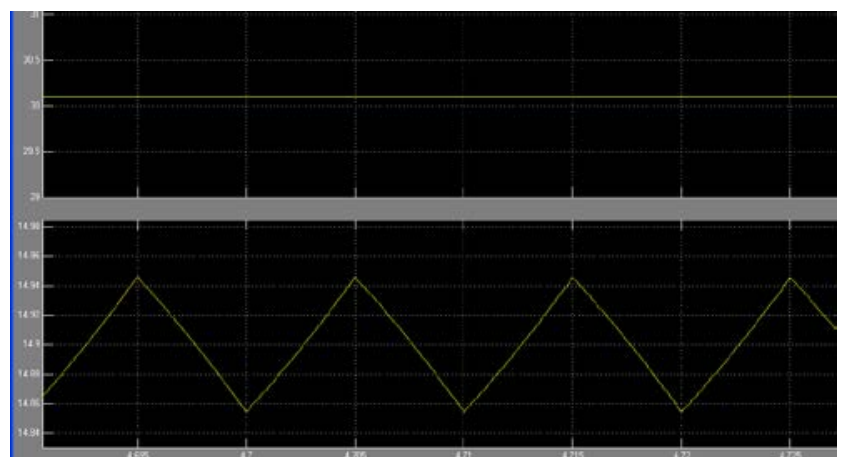

Fig. 15. Controlled output voltage from converter (c) Waveform from Battery

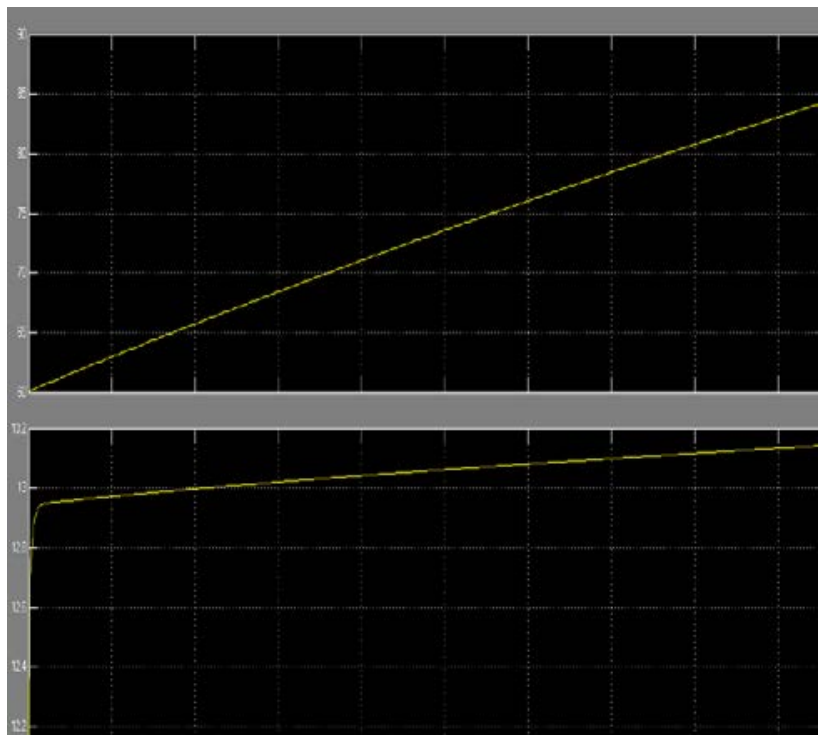

Fig. 16. Output curves from Battery. ( $1^{\text {st }}$ curve shows SoC and $2^{\text {nd }}$ curve shows battery voltage)

From figure 12 and figure 13, it is conspicuous that under temperature and irradiation variation, the short circuit current and open circuit voltage of the simulated PV module is about $4.75 \mathrm{~A}$ and $40 \mathrm{~V}$ respectively, which is nearly about the value of the data sheet of the testing model and it can deliver maximum power of $126.4 \mathrm{~W}$ which is also closer the data sheet value of the above mentioned model. Moreover from figure 15, it is seen that the MPPT with necessary control unit is quite capable of tracking the voltage for maximum power delivery which is about $30 \mathrm{~V}$. Again from figure 16, it is patent that the SoC of the battery varies from $60 \%$ to $80 \%$ when its voltage varies from $12 \mathrm{~V}$ to $13 \mathrm{~V}$, which is completely matched to the value of BCI standard for SoC estimation of a maintenance-free battery.

Eventually from the above result it is clear that the PV module based power system which is simulated here is fully capable of delivering maximum power about $126.4 \mathrm{~W}$ under cell temperature of $62^{\circ} \mathrm{C}$ and irradiance of $1 \mathrm{KW} / \mathrm{m}^{-2}$ with maintaining the MPPT and controlling of a $12 \mathrm{~V}$ battery to a $12 \mathrm{~V}$ DC load. Here simulation has been performed for a set of temperature and irradiation levels, so it can be said that this model can be used to test any PV module or even any PV array based power system under any irradiation and temperature conditions.

\section{Conclusion}

A complete off-grid PV module based power system has been designed, simulated and analyzed by MATLAB/Simulink using standard solar radiation data for Bangladesh. In order to achieve the performance, at first each components and subsystems have been analyzed and validated. Theoretically from the output characteristics of PV module, it has been shown that the module is capable to deliver $126.4 \mathrm{~W}$ maximum power to the load under the effects of certain irradiance $\mathrm{G}=1 \mathrm{KW} / \mathrm{m}^{-2}$ and temperature $\mathrm{T}=62^{\circ} \mathrm{C}$, which is very close to the desired data sheet value. MPPT is able to track the operating point of the photovoltaic module at the maximum power point level and the charge controller controls the charge of the battery as it has been shown in the simulation. It can be therefore concluded that a significant amount of additional energy can be extracted from a photovoltaic module by using simple maximum power point trackers and charge controllers and efficiency can be improved for the operation of renewable energy generation systems. The improved efficiency should lead to significant power savings in the long run and at the same time provides information about the types of devices that should be chosen. In conclusion, it can be said that this simulation model will serve as a good tool to test the performance of any PV module/array under the variation of temperature and irradiance condition.

Effect of shading or partial shadows on the operation of the module and different sorts of algorithms for better MPPT could be the future work of this type of problem.

\section{References}

1. James A Fay, Golomb S. Dan, 1998. Energy and the Environment, Oxford University Press., 150-155.

2. J.Ventreand, Messenger R.,2000. Photovoltaic Systems Engineering, CRC Press, New York., 230-235.

3. Sullivan C.R. and M.J. Powers, 1993. A high-efficiency maximum power point tracker for photovoltaic arrays in a solar-powered race vehicle, in Proc. 24th Annu. IEEE Power Electron. Spec. Conf., 846-852.

4. Wu W., N.Pongrantananukul, W Qiu, K.Ruston, T.Kasparis, and I. Batarseh, 2003. DSP-based multiple peak power tracking for expandable power system, Eighteenth Annu. IEEE Appl. Power Electron. Conf. Expo., 525-539.

5. Kuo Y-C., T-J. Liang and J-F Chen, 2001.Novel MaximumPower-Point-Tracking Controller for Photovoltaic Energy Conversion System, IEEE Transactions On Industrial Electronics, 48(3), 594-601.

6. Masoum M. A. S., H. Dehbonei and E Fuchs., 2002. Theoretical and Experimental Analyses of Photovoltaic Systems with Voltage and Current Based Maximum Power Point Tracking, IEEE Transactions On Energy Conversion, 17(4), 514-522.

7. Fangrui L., Y.Kang, Y.Zhang and S. Duan., 2008. Comparison of $\mathrm{P} \& \mathrm{O}$ and Hill Climbing MPPT Methods for Grid-Connected PV Converter., 3-5

8. Altas I.H., A.M. Sharaf, 2007. A Photovoltaic Array Simulation Model Matlab Simulink GUI Environment, ICCEP ’07.International Conference, 341-345. 
9. David L. King, 1996. Photovoltaic Module and Array Performance Characterization Methods for All System Operating Conditions of NREL/SNL Photovoltaic Program Review Meeting,18-22 November.

10. Teulings W.J.A, J.C Marpinard, A .Capel, and D.O Sullivan, 1993. A new maximum power point tracking system, in Proc.24th Annu. IEEE Power Electron. Spec. Conf., 833-838.

11. Jiang Y., J.A.A Qahouq, and I Batarseh, 2010. Improved solar PV cell Matlab simulation model and comparison, 2770-2773.

12. Masoum Ali S., Padovan, Frank, Masoum, A.S. Mohammad, 2010. Impact of partial shading on voltage- and current-based maximum power point tracking of solar modules, Power and Energy Society General Meeting, IEEE, 1-5.

13. Patel H, V.Agarwal, 2008. MATLAB-Based Modeling to Study the Effects of Partial Shading on PV Array Characteristics, Energy Conversion, IEEE Transactions on,23(1), 302-310.

14. Ramaprabha R., B.L.Mathur, 2009. MATLAB Based Modelling to Study the Influence of Shading on Series Connected SPVA, Emerging Trends in Engineering and Technology, $2^{\text {nd }}$ International Conference, 30-34.

15. Akihiro Oi, 2005. Design and Simulation of Photovoltaic Water Pumping System Master's Thesis, California Polytechnic State University, San Luis Obispo.
16. Mutoh Nobuyoshi, Takatoshi Matuo, Kazuhito Okada, Sakai Masahiro, 2002. Prediction Data based Maximum Power Point Tracking Method for Photovoltaic power generation systems. Power Electronics Specialists Conference, IEEE 33 ${ }^{\text {rd }}$ Annual, 3.

17. Ned Mohan, Tore M. Undeland, William P. Robbins, 2003. Power Electronics: Converters, Applications, and Design, 3rd Edition, Wiley.

18. Middlebrook R.D. and S.Cuk, 1976. A General Unified Approach To Modeling Switching-Converter Power Stages, IEEE Power Electronics Specialists Conference, 18-34.

19. Exide Management and Technology Company, Handbook of Secondary Storage Batteries and Charge Controllers in Photovoltaic Systems - Final Report, for Sandia National Laboratories, SAND81-7135, August 1981.

20. Harrington and Dunlop, 1992. Battery Charge Controller Characteristics in Photovoltaic Systems, Proceedings of the 7th Annual Battery Conference on Advances and Applications, Long Beach, California.

21. BP Solar BP SX150- 150 Watt Multi-crystalline Photovoltaic Module Datasheet, 2001. 